\title{
Beyond community-based tourism. Towards a new tourism sector classification system
}

Más allá del turismo comunitario: hacia un nuevo sistema de clasificación turística

\section{Andrea Giampiccoli}

Department of Hospitality and Tourism (Ritson Campus). Durban University of Technology. Duban, South Africa

andrea.giampiccoli@gmail.com

Oliver Mtapuri

College of Humanities School of Built Environment and Development Studies. Howard College Campus University of KwaZuluNatal. Durban, South Africa

simbaomtapuri@yahoo.com

\section{RESUMEN}

Los adversos efectos socioeconómicos, psicológicos y ambientales del turismo convencional, o de masas, provocaron la aparición de nuevas formas de turismo como el turismo comunitario. Esta forma de turismo presenta características prometedoras y alternativas como el empoderamiento de la comunidad y la sensibilidad medioambiental que podrían aplicarse a los sistemas de clasificación (rating/grading) turísticos. Este artículo presenta un nuevo e innovador sistema de clasificación turística inspirado por estos principios del turismo comunitario. El artículo se basa en trabajos previos de los autores y en ideas provenientes de la literatura especializada y su contribución principal es una propuesta de modelo de clasificación turística que, inspirada en el turismo comunitario, incorpora aspectos como la equidad, la educación, el empoderamiento, el carácter endógeno y la sensibilidad ambiental como pilares y criterios para la clasificación turística. La aplicación de este sistema de clasificación requeriría de incentivos oficiales ya que la mayor parte de estos sistemas son de carácter voluntario.

\section{ABSTRACT}

The adverse socio-economic, psychological and environmental impacts of conventional/mass tourism prompted the emergence of new forms of tourism such as community-based tourism. This form of tourism manifests promising and progressive characteristics such as community empowerment and care for the environment with potential of these characteristics to be harnessed for rating/grading of facilities. This article presents a novel and innovative rating/grading system which leverages these CBT principles. The article is based on previous work and insights on grading systems from the extant literature. The major contribution of this article is the E-based model of facility classification system. The proposed classification system incorporates aspects such as Equity; Education; Empowerment; Endogenous; and the Environment as pillars/criteria for grading facilities. The operationalisation of this grading system has policy implications in that it requires incentives from the government given that most grading systems are voluntary.

\section{PALABRAS CLAVE}

sistemas de clasificación turística | turismo comunitario

KEYWORDS

classification | grading | rating system | community-based tourism

\section{Introduction}

Tourism is a growing sector with the potential and influence to shape a country's development, as corroborated by Honey and Gilpin (2009: 9) who argue that since it is a global industry its potential can also be both positive and negative. Tourism has been advanced as a development tool in both developed and developing countries (see Sharpley 2009: 40, and Saarinen \& Rogerson 2014: 24). For example, with reference to the African context, the Secretary General of the World Tourism Organization (UNWTO) stated:

"Tourism is one of the Africa's most promising sectors in terms of development (...). Africa has a major opportunity to harness the potential of tourism to foster development and increase its 
participation in the global economy. In addition, tourism creates opportunities for millions of host communities in Africa and provides revenues for cultural and environmental preservation" (Rifai 2015a: 2).

Thus, the role of tourism in development has been widely covered in tourism literature with authors coming to the consensus that tourism has the potential to act as a vehicle for economic development, the generation of jobs as well as for poverty reduction (Novelli 2016: 1). However, it is worth noting that conventional/mass tourism has manifested many problems, around the issues of "consumption, exploitation and globalization" (Singh, Timothy, Dowling, 2003: 5) as well as issues related to its sustainability under current application and practices (Spilanis \& Vayanni 2004: 272). As a consequence to the negative matters related to conventional/mass tourism, alternative forms of tourism have emerged (Luo, Brown \& Huang 2015: 292). These alternative forms to mass tourism are varied as Loizos-Christou (2012: 1) observes:

"Alternative tourism incorporated soft tourism, small-scale tourism, green tourism, nature tourism and integrated tourism. Alternative tourism was used as a hope for proving consistency with natural, social and community values, as alternative tourism could have less negative effects on destination areas, environment and population without diminishing positive economic effects. Alternative tourism grew rapidly and out of the need to remedy mass tourism's negative impact on the environment and society, which could affect the attractiveness of a given destination from a long term perspective. Alternative tourism emphasized the idea of preserving social, natural and historical assets of tourist destinations" (Loizos-Christou 2012: 1; see also Honey \& Gilpin 2009: 3 on a similar tone and from an ecotourism perspective).

As a way to overcome problems associated with conventional/mass tourism, in terms of timeframes, alternative tourism emerged during the 1970s (Fennell 2006: 4, Singh, Timothy, Dowling 2003: 5). Along this line of thought, the emergence of Community-Based Tourism (CBT) can also be interpreted as a direct reaction to the adverse impacts of mass tourism to shape a different and unique tourism approach (López Guzmán, Sánchez-Cañizares \& Pavón 2011: 73). While CBT has its distinct features, and needs to be recognized for what it is, it has its strengths, weaknesses, vulnerabilities as well as sustainability issues. It is no wonder that a CBT project can fail (see for example George, Nedelea \& Antony 2007: 4). This paper discusses its potential for expansion and percolation of its principles to the wider tourism sector with a focus on its fundamental principles.

Caution has been thrown on conventional tourism development such that "the realization of the impact of mass tourism and conventional tourism development, many destinations and authors have advocated caution in the scale and pace of tourism development" (Oriade \& Evans 2011: 72). Leakage, for example, is a major issue, and the UNEP (No date) observes that of every $\mathbf{S} 100$ spent by a tourist from a developed country on a vacation, just about US\$ 5 remains in the developing country visited. UNEP (No date), mentioning a study done in Thailand and other countries indicate that about $70 \%$ of the money spent by tourists left Thailand through foreign owned entities such as airlines, hotels and tour operators including through imported food and drinks with leakage estimates for other Third World countries in the region of $80 \%$ for the Caribbean and $40 \%$ for India. Thus, tourism can be a negative force if not properly managed as it affects many sphere of society with profound socio-economic and environmental impacts. As Tresilian (2006: 20) observes tourism development which is not properly managed has the potential to depend existing inequalities, create economic imbalances through commercialisation of local cultures and the unfair and unequal distribution of tourism benefits including adverse impacts on the environment.

Poverty and inequality are relevant issues with this discourse (and are growing) and remain current matters of concern in both developed and developing countries and more so given their interrelationship (Pickett 2014: 1-5, UNDP 2013: 7, OECD N. d: 3). Other writers have noted that tourism itself is a factor that can contribute to inequality because it has always provided that platform for social inequality and as it expands at a fast pace, its impacts become evident especially inequality, calling for deeper and nuanced understandings of these manifestations (Cole \& Morgan 2010: XV). Tourism can create opportunities for the poor, thus, Ivanovic (2008: XXI) observes that organizations such as Unesco, Nepad, the World Bank, UNWTO and SADC have identified tourism as an effective tool to spur development in developing countries by creating the chances and opportunities for economic growth, earning foreign currency and for reducing poverty. There is evidence suggesting that growth in tourism does not necessarily lead to poverty alleviation, because in some cases poverty has been exacerbated (Saayman, 
Rossouw \& Krugell 2012, Gartner \& Cukier 2012: 561). In this context, it is important to indicate that there is also evidence suggesting that in places or neighbourhoods in which inequality is high, civic participation and trust are low (Lancee \& van de Werfhorst 2011: 9).

In this same vein, it is important to note that although it seems utopian to think that even sustainable tourism will not have any impact on the environment, any initiatives to move away from conventional tourism and the application of alternatives is for as long as it contributes to the area's sustainability (Spilanis \& Vayanni 2004: 273). At the same time, it cannot be denied that tourism can be a good thing. In other words, tourism can be good if properly managed and for Honey \& Gilpin (2009: 9), tourism can be a good force in efforts to alleviate poverty and for peace depending on how it is configured, managed and planned.

Thus, this article, proposes an "action plan" represented by a new rating classification system which is based on alternative forms of tourism (but specifically community-based tourism) and its principles in order to make tourism a "good thing" than a "bad one". This article will not delve or investigate the relation between tourism and the various forms of inequalities but it will present a new rating classification system for the tourism sector which could contribute towards a more sustainable, participative and just tourism sector. As such, this article builds on, reconceptualises and re-contextualises a CBT model proposed by Giampiccoli, Jugmohan \& Mtapuri (2015) which indicates the basic fundamental matters within which CBT development should be evaluated and understood.

The article proposes a new rating classification system which leverages on the fundamental concept related to CBT in order to expand and percolate CBT principles into the whole tourism sector. This will not eliminate all problems in the sector tout court, but contribute towards its restructuring and the adoption of just principles and practices for the betterment of societies in which tourism is practised, produced and re-produced. In consideration of the problems related to conventional/mass tourism, this article will also reflect on the challenges of inequality and poverty in both rich and poor countries in order to the matter into a proper perspective. In that pursuit, the proposition of the establishment a new rating classification system for accommodation is presented. While the present example is based on accommodation, the same new rating classification system (with possible adjustments based on a specific type of business entity) could and should be applied to the various entities such as tour operators, travel agencies, restaurants, car rentals, and so on, which are involved in the tourism and hospitality sectors. After this introduction, which sets out the rationale and background for this article, the literature review will follow and it will comprise two main sections: the first section proposes CBT and its fundamental matters upon which the new rating system is built; and a second section provides issues related to a rating classification system and consequently proposes a new system. The last section concludes.

\section{Methodology and Literature review}

This conceptual article is based on material gathered from a perusal of extant literature on tourism in general and community-based tourism in particular. Secondary sources are important as repositories of knowledge upon which others can leverage, obviating the need to collect primary data, in the pursuit of knowledge production.

\subsection{Community-based tourism}

Scott (2015: 41) observes as did Novelli (2016: 1) concerning tourism in general that the spouting of alternative types of tourism is a consequence of the overlap associated with tourism and the development of poor and remote areas with topics such as rural tourism, pro-poor tourism, ecotourism, ethnic tourism and community-based tourism emerging. Amin and Ibrahim (2015: 539) propose that CBT is important in many countries such as Cambodia, Thailand, Indonesia and others in Africa, the Caribbean, Europe and Australia as a crucial facet of the tourism industry.

Amir and others (2015: 117) acknowledge the support CBT receives from international organisations such as the World Tourism Organization because of its potential to enhancing the visitor experience, to conserve the cultural and natural resources of the host nations and the empowerment of communities. It can be surmised that each form of tourism can have its own types of influence on the shape and course of 
development and overall CBT is seen to have largely positive outcomes and this view is supported by Tamir (2015) on the argument that it is the manner in which the CBT projects are developed, nurtured and managed that matters especially within of the scope of integrating cultural and natural conservation with income generation. In this context, the manner in which CBT principles are developed, managed and expanded in the whole tourism sector is indicative of the level of influence that CBT can have in the tourism industry as a whole. In that vein, this article propounds the new rating classification system as a possible way to percolate the CBT principles into the whole tourism sector. CBT can be a good starting point as Tamir (2015) argues that it can be practised at minimum costs with maximum benefits and bring economic prosperity, both environmental and cultural awareness as well as peace.

CBT has been linked to various definitions and understandings and CBT development could take a variety of development trajectories (see Mtapuri \& Giampiccoli 2014). However in the context of this article and with the support of various literature, CBT is defined as a type of tourism that it is "managed and owned by the community, for the community, with the purpose of enabling visitors to increase their awareness and learn about community and local ways of life" (George, Nedelea \& Antony 2007: 1; see also on similar perspective Suansri 2003: 14, Ramsa Yaman \& Mohd 2004: 584, Kayat 2014: 1, Mtapuri \& Giampiccoli 2013, Leksakundilok \& Hirsch 2008: 214). Put differently, George, Nedelea \& Antony (2007: 2), observe that CBT provides communities with opportunities to participate and opportunities to make decisions in pursuit of conservation and development with benefits accruing to the community. These principles of ownership and management, and benefits, by and for the community, should be considered as the first and fundamental feature in CBT. A CBT approach can provide a multiplicity of benefits at various levels as such, for example, community-based ecotourism sites provide spaces for earning foreign currency, for job creation and improvement of the general conditions of communities (Manu \& Kuuder, 2012: 98). In addition, CBT development does not necessarily require major investments, even if specific policies and legislation can influence its success or failures (Tresilian 2006: 14).

The literature presents various CBT characteristics, pre-conditions and challenges including, amongst others, the need for CBT to be endogenous in nature. In addition, CBT should be seen as a complementary activity (at least in its beginning), CBT should have individual- and community-wide benefits, and CBT should be linked to skills and education promotion (see Saayman \& Giampiccoli 2016, Jugmohan \& Steyn 2015). Marketing, scarcity of local resources and capacities are amongst the challenges that hamstrung CBT projects (see Saayman \& Giampiccoli 2016: 152) as well as issues related to infrastructure, physical/natural and cultural tourism assets. Market access and marketing are also seen as a precondition for evaluating CBT development (see Jugmohan \& Steyn 2015). In moving towards deeper and comprehensive understandings of CBT features, it has been argued that CBT should reflect a type of tourism which promotes a number of objectives related to conservation and development in its broadest terms to include socio-economic and related matters including the protection of culture and the environment (Tamir 2015: 51). Tamir (2015: 51) avers that CBT participatory and development approach as it empowers local communities by enhancing their knowledge, skills and confidence to manage their community resources and take control over them; and "If effective and successful, CBT may bring to healthy economic development, cultural and environmental awareness, cross-cultural understanding and peace and sustainable destination development". For Yoopetch (2015: 573), CBT involves collaborative activities, social capital creation as well as the re-distribution of power including the four dimensions of related to sustainable development, namely, "economic viability; ecological sustainability; equitable distribution of costs and benefits; and good governance" (Yoopetch 2015: 574). Education and capacity building in CBT is also seen as a key factor and should be considered as an important pre-condition in CBT development (Giampiccoli, Jugmohan \& Mtapuri 2014). Beyond conservation and development, George, Nedelea \& Antony (2007: 3) proposed the following characteristics of CBT:

A community-based tourism project is a profitable and sustainable activity that enhances the environment while adding value to the experience of both locals and visitors.

- It directly involves the community - providing both social and economic benefits.

- Its ultimate goal is to satisfy consumer expectations without harming the community interests.

- It is market driven and has to meet high standards in order to be sustainable.

- Private entrepreneurs, community groups, and or organizations may own it. It should aim to educate, train, develop, encourage, and utilize any skills and human potential within the community, towards the 
delivery of professional service.

- It should be operated within a business structure that adheres to government regulations, financial obligations, good labour relations and sound management systems.

- All Business Plans must be scrutinized to ensure owners/organizations understand the opportunities, pitfalls and risks and to show the long-term viability of the Project.

- Environmental awareness and sustainability should be top priority. It is the responsibility of the community to maintain clean healthy surroundings.

- Members of the community are expected to exhibit friendliness, honesty and professionalism amongst themselves as well as in their dealings with the visitor to ensure the integrity of the project.

Furthermore George, Nedelea \& Antony (2007: 2) indicate that noteworthy benefits to community include reduced impact on both culture and the environment as induced under mass tourism; poverty alleviation and the generation of jobs; as well as income to maintain and rehabilitate community cultural assets. After a perusal of various pieces of literature, Giampiccoli et al. (2015) propose a E's model (see below) related to CBT fundamental principles or pillars within which CBT should be monitored and evaluated. These principles are re-introduced for this article with specific adjustments (in Italics):

Endogenous: CBT should be an indigenous local efforts, should rely on local resources and cultures, knowledge, expertise and so on.

Environment: especially when reference is made to community-based ecotourism (CBET) and the conservation of the biodiversity should be paramount. This group, should also include issues regarding health and sanitation in the sense of environmental conditions and also include available infrastructures.

Education: increase in skills, attitudes and education related to CBT (tourism) and generally.

Empowerment: entails holistic empowerment which embraces economic, psychological, social and political empowerment.

Equity: equal distribution (and working towards re-distribution) of benefits and resources amongst the people involved and in the wider society and between men and women.

Evolving: always improving and changing bases based on the need and the specific changing conditions and opportunities, for example, from informal to formal sector and vice versa.

Enduring: long term sustainability in all the various aspects (cultural, economic, environmental, psychological and social).

Entrepreneurship: keep in consideration all the entrepreneurial characteristics. The CBT ventures is, like any other business, has to be economically viable, with proper accountability, a management system, appropriate decision making processes, networking and so on.

It is important to add that from a visitor's perspective, CBT can be linked to the new (post-modernist) tourist types which are characterised by such features which discerning tourists look for like 'authenticity', exoticism, and wishing to learn and educate themselves about the places they visit (Mtapuri, Giampiccoli \& Jugmohan 2015, Dolezal, 2011: 131, and Fiorello \& Bo, 2012). Importantly, CBT is not necessarily small scale and its development to a larger scale has been observed (see Saayman \& Giampiccoli 2016). Within this context, this article intends to propose a new rating classification system to influence and infuse into the whole tourism sector CBT principles. This spread will go beyond tourism to society as a whole thus:

"while CBT concepts and practices should strongly and unconditionally continue to prioritise and be specifically related to (and holistically benefit) disadvantaged communities' members within a redistributive and social justice framework at global and local level, it should also spin off to all tourism sectors. As such, CBT should work to localise the ownership and control of the tourism sector as a whole. While CBT must be much more proportionally directed to offer a strong and decisive advantage to disadvantaged communities' members (vis-à-vis more powerful/wealthy groups of society) and must strongly and holistically decrease the inequality gap between various groups of society at various geographical levels, it should influence and circumscribe the whole tourism sector (and society) to enhance the local control of, and local benefit from, tourism" (Saayman \& Giampiccoli 
2016: 166, emphasis in original).

The new rating classification system which is presented below can be considered as one possible option (in as much as other options could also emerge) which could work towards the expansion of CBT principles in the whole tourism sector.

\subsection{Rating classification systems}

The key terminologies used in classifications need to be kept in perspective to avoid misunderstandings and thus it is here proposed that "The terms, 'hotel rating', 'hotel grading', 'hotel classification' and 'hotel segment' are used interchangeably to distinguish hotels for their price, service, and facility levels" (Rhee \& Yang 2015: 577; also UNWTO 2015: 10). Following the UWTO definition, hotel classification is here defined as "the ranking of hotels, usually by using nomenclature such as stars (or diamonds), with one star denoting basic facilities and standards of comfort and five stars denoting luxury in facilities and services" (UNWTO 2015: 10). The aim of hotel classification is "to inform intending guests in advance on what can be expected in order to reduce the gap between expected and experienced facilities and service delivery" (UNWTO 2015: 10). However, in this article the ranking will not be based on facilities and service delivery but innovatively in matters related to CBT principles for grading facilities.

Despite the change in tourism behaviour, rating classification systems are still seen relevant, thus "even as travellers become increasingly adventurous, seeking new and unexplored destinations, they still demand certain indicators of what they are about to experience and official hotel classification systems have long provided such indications/information relating to accommodation" (Rifai 2015b: 5). In the accommodation industry, hotel ratings are extensively used to inform both consumers and intermediaries on each accommodation establishment's standards, however confusion is still present because there are many systems of grading worldwide and notably there are five approaches however with each having its own processes and practices -further confusing the customer in a global world" (UNWTO 2015: 6).

There are studies which have examined hotel ratings/classifications in literature (see Rhee \& Yang 2015, Radojevic, Stanisic \& Stanic 2015, Núñez-Serrano, Turrión \& Velázquez 2014, Su \& Sun 2007, and Callan, 1994). For example López Fernández \& Serrano Bedia (2004: 771) investigated whether "a hotel classification system is a good indicator of hotel quality". However, a common denominator reference in most of the studies relates to the problem of diversity and harmonisation of the classification systems between and, sometimes within countries (see for example Su \& Sun 2007: 92, Radojevic, Stanisic \& Stanic 2015: 15, Rhee \& Yang 2015: 15, Núñez-Serrano, Turrión \& Velázquez, 2014: 78). Despite the diversity in classifications, there is some common denominators in the systems in terms of commonalities which unite accommodation facilities of different standards around the world, and such commonalities and differences do assist destinations to calibrate their classification systems in ways which are relevant to hotels, intermediaries and consumers alike (Rifai 2015b: 5).

In this vein, attempts to compare and even unify the rating systems across countries have been done. As such, for example, UNWTO (2015) reports on a comparison of classification criteria for 4 and 5 stars hotels in global and European specific groups which shows that in spite of the existence of many classification types, more similarities exist than there are differences, between star categories and geographic groups (UNWTO 2015: 6). Radojevic, Stanisic \& Stanic (2015: 14) also observe a lack of cohesion and international standards in hotel rating. It can be said that the fragmentation in classification systems "gives rise to problems, of supply and demand" and "with regard to consumers, stars can mean nothing if the criteria for the assignation of such stars vary greatly from country to country and region to region, thereby aggravating the problem of asymmetric information" (Núñez-Serrano, Turrión \& Velázquez 2014: 78, and Cser \& Ohuchi 2008).

On the variety of classification criteria, a European study (The European Consumer Centres' Network No date: 3 ) notes that the existence of various classification systems within Europe is a problem and argues for more discussion on the creation of a harmonised and convenient classification system which the industry could use in meeting the consumer's rights. The European Consumer Centres' Network (No date: 7) observes that in many countries the criteria used to classify hotels "have character, technical rules in which qualitative aspects are less represented and (...) can be divided into two categories: 1 ) area and equipment, including, in particular, criteria on surfaces (the rooms), toilet facilities (including the proportion of rooms with bathrooms with tub and shower), and endowment with furniture and other 
objects; 2) Quality criteria in relation to the quality of facilities, services and quality". Whereas, comparison criteria in the UNWTO (2015) contained Room; Food and Beverage; Bathroom; Services; Front Desk; Public Areas; Access; Exterior and General; Communication; and Temperature Control. The East African Community (EAC) (2010) also mentions an attempt to compare and standardize multi-countries classification and some of the criteria include: Location; lobby/lounge/public area(s); Bar(s); Guest rooms; and Guest bathroom(s). Su and Sun (2007: 393) also note the existence of various classification systems observing that since the 1990s, there have been a number of studies comparing them.

At a country level, Canada, for example, maintains that in its rating system for hotel/motel the process includes public areas, guest bedrooms and bathrooms, exterior and interior of the property, food and beverage services and additional services" (Canadian Star Quality Accommodation 2013: 2). In South Africa, the Tourism Grading Council of South Africa (TGCSA 2013) adopted standard criteria which include criteria such as building exterior; bedrooms; bathrooms; public areas; general facilities and specific criteria which include dining facilities; additional facilities; and responsible environmental and business practices. All these classification systems mostly show that the focus of classification is based on the quality and services of the accommodation establishment such as bathrooms, reception, exterior appearance and so on and very seldom other factors beyond quality and service. This is not to say that this form of classification based on quality and service is not important, in fact it is to show the quality and service standards of accommodation establishments so that the industry and the customers are aware of the various levels of standards at each establishment. This is also supported in the literature by Radojevic, Stanisic, Stanic (2015: 140) who observe that: "Star ratings, which are primarily determined by physical aspects of a facility and its service quality, act to reflect the degree of luxury of a hotel, and moreover provide an effective proxy for prestige among international hotels." (Radojevic, Stanisic \& Stanic 2015: 14).

While these criteria are important, they should not be the only ones but be part of the many aspects against which a hotel should be evaluated to have a more comprehensive classification which includes issues related to social equality, the environment and so on should be also considered.

Admittedly, there are alternative classification (or at least accreditation) systems which are not necessarily based on quality and service but focus on social and environmental matters. For example, the Green Globe certification "is a structured assessment of the sustainability performance of travel and tourism businesses and their supply chain partners" and it uses criteria based on sustainable management, social economic, cultural heritage, and environmental (Green Globe, no date). Fair Trade is another certification approach, thus Fair Trade Tourism (FTT) certifies tourism businesses based on criteria which includes: business practice and human resources; community resources; cultural heritage; and environmental practice (FTT, no date). Another certification system is the Certification for Sustainable Tourism (CST). The CST "is one of the first systems, if not the first, to achieve the integration of the principle elements of sustainable tourism, analyzing good management practices, the environmental and social impacts of services, as well as the client's perception of image and the congruence between the service offered and the product's promotion" (CST 2003). CST started in Costa Rica and it is hoped to be extended to other countries, and its spread is envisaged to bring benefits such as cost reduction, improved occupancy and image with substantial spinoffs to the environment as well as providing social guarantees to the local people and at the regional level, it is envisaged to "serve as a unifier and a common basis for the promotion of sustainable tourism" (CST 2003). Following this emerging trend of new classification/certification approaches, and trying to go beyond them in a comprehensive manner by including more innovative considerations, this article proposes such a new possible classification based on CBT principles and which aims to combine a comprehensive list of social, economic, cultural and so on aspects as well as propose a possible new comprehensive alternative classification system. In this article, the new rating system -whose ambition is to contribute to homogenising specific attributes of companies in the tourism sector- will propose a model that will indicate the fundamental underlying commonalities that such new rating system should adhere to informed by the CBT Es presented below.

\section{Towards a new classification/rating system}

Based on extant literature on CBT characteristics and expanding on what was proposed by Giampiccoli, Jugmohan \& Mtapuri (2015), a new rating classification system is presented with the ambition to ensure 
the spread of the CBT fundamental principles into the whole tourism sector. The purpose is to percolate the whole tourism sector and thus to contribute towards its shift towards embracing the fundamental and progressive principles of CBT. This initiative is not intended to "convert" the whole tourism sector into a CBT "sector". While this "conversion" can be hoped for and work in this direction is worthwile and welcome, it is considered as a long term project which is unrealistic at this stage as well as in the short term. The proposed new classification system's intention is to assist the sector to move towards adopting CBT principles in order to contribute to a just tourism sector.

Thus, this article proposes a new rating classification system which goes beyond CBT (but based on its fundamental principles) in order to infuse the whole tourism and hospitality sectors. While the proposed new E's rating system is not in conflict with current rating systems based on service and quality, it is complementary to it. Ideally each tourism business should use both systems in order to be more comprehensive and with the inclination to restructure the various aspects (and not just one such as the environment). This would represent a new alternative rating classification system. The E's rating classification system will include the previously proposed E's (see Giampiccoli et al. 2015) with some extra E's. Thus the E's system will be based on the following E's: Endogenous, Environment, Education, Empowerment, Equity, Evolving, Enduring, Entrepreneurship and new E's. Specifically two more E's could be added in this context (and are in addition to the previous model proposed by Giampiccoli et al. 2015). These new E's are:

- Ethical: respect of laws, respect of gender relations and disadvantaged groups, respects for human and animal rights and so on.

- Externalities: positive impact on the local context in which the company operates, cultivating active and valuable relations/cooperation with other entities, reflecting a sense of responsibility to the local context and nurturing good relationships.

Finally, a number of new E's are included to have a specific and enhanced guest perspective and cater for guest requirements. These are:

- Exclusive: a special and unique experiences to the visitors.

- Experience: knowledge, involvement and specific experience for the visitors

- Enjoyment: contribute to the enjoyment of the visitors.

- Ethnic: to respect local traditions such as traditional building methods, architecture, use of the present landscape as used by the business and so on (The Ethnic E could also be viewed from a tourism business perspective as a way to respect local traditions in the business practices -such as an Ubuntu management system in many African contexts- as well as building/construction and so on).

While the new system is not comprehensive, the following example aims at giving an indication and the direction that the E's rating classification system should adopt in order to restructure and move towards CBT principles in the whole tourism sector. More research and work should be done to comprehensively finalise the E's rating system using all its various E's. Table 1 shows the example of the ' $E$ ' for Endogenous showing a number of possible items/indicators and various levels of sub-items/sub-indicators which are possible. The aim is to list all the possible items within the concept of 'Endogenous' but related to CBT which could be used in the whole tourism sector (accommodation or other subsectors such as tour operators).

Table 1: The endogenous characteristic

\begin{tabular}{|l|l|l|c|}
\hline \multicolumn{3}{|c|}{ Endogenous } & \multicolumn{1}{c|}{$\begin{array}{c}\text { Rating } \\
\text { (one to five stars) }\end{array}$} \\
\hline \multirow{4}{*}{ Local ownership } & Collective ownership & Cooperative & \\
\cline { 2 - 4 } & & Trust & \\
\cline { 2 - 4 } & Partnership & & \\
\cline { 2 - 4 } & Sole proprietaries & & \\
\cline { 2 - 4 } & $\cdots$ & & \\
\hline & Local architecture & & \\
& & & \\
& & &
\end{tabular}




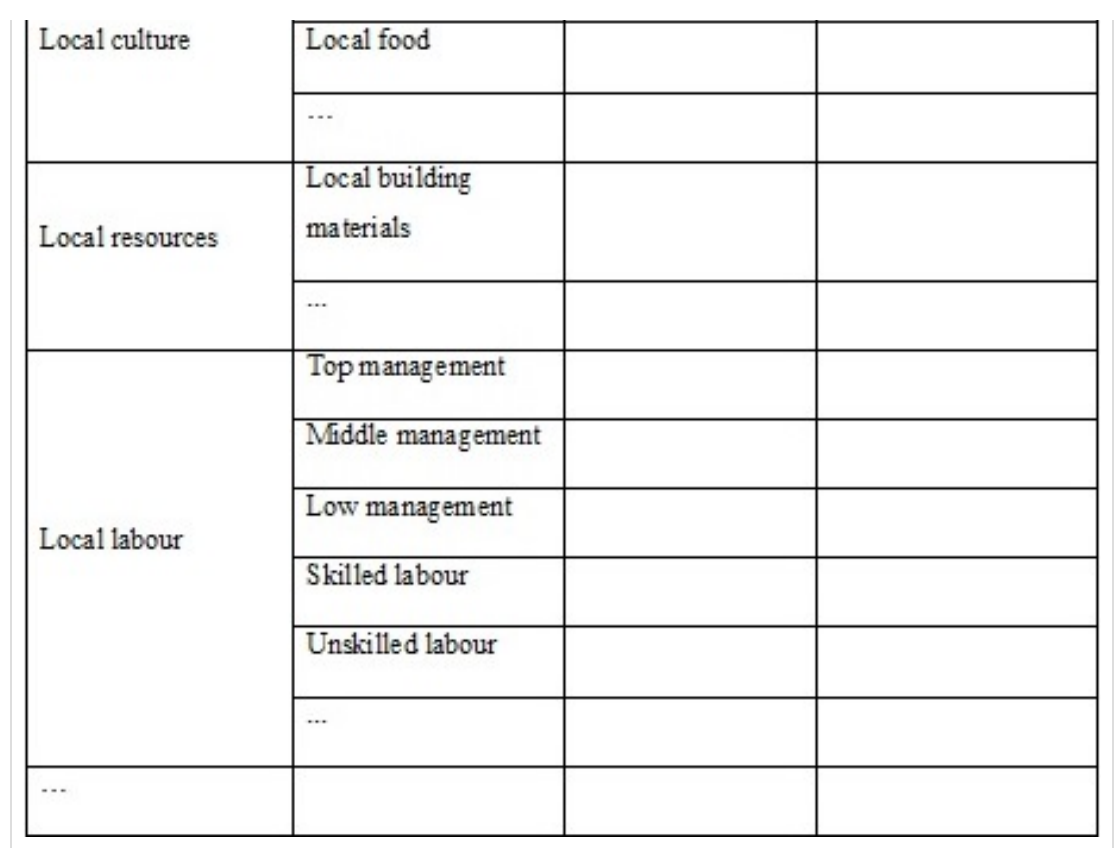

Furthermore some E's could be used from both a business and visitor perspective, thus Education could be understood from the perspective of both staff and tourists. Thus, while Education for staff means to enhance their skills and education (of staff) in relation to tourism and also in general, Education in relation to tourists will mean to facilitate the tourism business (such as a Hotel) through the enhancement of education, which is the learning experience of the tourist in relation to the various aspects of the local context. As such, as an example, a hotel could organise (inside its premises or outside) specific workshops on the history of the place or on lessons on how to cook traditional foods, or it could organise specific educational tours or even present within the same hotel premises specific artefacts or other items showing the various aspects of the local history and tradition. In this way, it becomes a kind of 'museum hotel' where guests can learn within the hotels about the local (surrounding) contexts.

As such each E's should be developmental with its own specific items and sub-items and while some common international based commonality should be established as an international standard and a basic frame of reference for the E's model and rating system, it is envisaged that more specific and nationally based items could also be added to provide a better fit which is specific to local contexts and requirements.

In addition, it is also proposed that specific enterprises could be developed based on the basis of the E's model to serve to attract specific market segments of tourists who are more predisposed to pay attention to the impacts of tourism on the various local contexts. In this regards, while company could transform themselves to comply to various degrees with the new rating system, it is proposed that new company(ies) could also be establish based on the new rating system in order to conform already as much as possible to the new rating system. As such, for example, new tourism businesses based on collective management and within national and/or international specific organisations could emerge and provide the prospective shift of the tourism sector towards embracing the progressive CBT principles. This new company(ies) could work in cooperative franchise systems under an umbrella organisation and with standard requirements but flexible enough to be able to operate in each specific context based on need. Further research could explore the details of the development characteristics, requirements and possibilities of this new enterprise-based system. Additionally, from a market perspective, the new company has the potential to appeal to the new (postmodern) and young tourism market segment that searches for more sustainable, ethical and people- and local-context-centred types of businesses and experiences.

The hotel (or other tourism business) which adheres to the innovative E's model could be denominated as an E-Hotel (or E-Travel agency and so on) and be awarded a specific number of E's or stars. The specific number of E's should relate to when the Hotel applies to be evaluated based on say only one or more specific E's. For example, a hotel could be judged only in relation to the Environment and Endogenous aspects, while the stars system could be used when a Hotel applies to be evaluated against the full E's model. Certainly, this second option is seen as ideal and most valuable for both the Hotel and the tourists 
in their quest for specific Hotel credentials and proviso of choice.

\section{Discussion}

The new rating classification system does not conflict with most conventional quality/service based rating and classification systems. In fact, the new E's rating system does not include matters of quality/service as the present rating are considered as satisfactory or to other forms of classification and/or accreditation such as Fair Trade or Green, as it aims to be an alternative system that is based on CBT principles which includes a more comprehensive range of progressive and innovative aspects of a developmental nature. Certainly the fact that most, if not all, the rating, classification and certification systems are voluntary will possibly and highly jeopardise their possible potential and adoption. As such, it is recommended that the E's classification system (as any other classification system for that matter) should be legally enforced or, at least, be backed by a strategy or set of incentives which makes it advantageous to be classified/rated /certified for companies on the E-model. In this context, specific tax incentives and other strategies could be explored and evaluated to enable implementation. For example, a greater compliance with the E's model rating could increase specific competitive and comparative advantages for the tourism company -this advantage could be enhanced by the fact that the tourism company will adopt and "advantage" the E's model with more benefits attuned for the local context, environment and so on. This last matter has been already addressed specifically to answer on the question: "Why have a classification system? The reason is simple as Pierret (2013) notes classification and rating in some countries "serves as a reference for the implementation of public policies, such as the granting of subsidies or certain tax breaks".

\section{Conclusion}

This article discussed the emergence of CBT as a consequence of the adverse effects of conventional/mass tourism on its failure to address the issues of job creation, poverty and inequalities and degrading the environment. The article also looked at existing grading/classification systems which are mainly based on service and quality. New and innovative grading systems have attempted to incorporate new characteristics relevant to current times such as the environment. It then posits an E-based classification system for grading facilities. The proposed new system leverages on the progressive and innovative CBT principles. This article argued that the use and spread of the progressive CBT principles bodes well for the whole tourism sector as this could provide a platform for the creation of "progressive" companies whose creation is steeped in those principles.

\section{References}

Amin, Wan Mohd (and Yahaya Ibrahim)

2015 "Model of Sustainable Community Participation in Homestay Program", Mediterranean Journal of Social Sciences, $n^{\circ} 26$ (3, S2): 539-545.

Amir, Ahmad Fitri (and others)

2015 "Sustainable tourism development: A study on community resilience for rural tourism in Malaysia. Procedia", Social and Behavioral Sciences, $\mathrm{n}^{\circ}$ 168: 116-122.

Callan, Robert

1994 "Statutory Hotel Registration and Grading", International Journal of Contemporary Hospitality Management, $\mathrm{n}^{\circ} 6(3): 11-17$.

Canadian Star Quality Accommodation 2013 Standards for hotels \& motels. Retrieved 1 October 2015 from http://www.ahla.ca/wp-content.pdf

Cole, Stroma (and Nigel Morgan)

2010 "Introduction: tourism and inequalities", in S. Cole \& N. Morgan (eds.), Tourism and inequalities. 
Problems and prospects, XII-XVII. Wallingford, CAB International.

Cser, Kate (and Anne Ohuchi)

2008 "World Practices of Hotel Classification Systems", Asia Pacific Journal of Tourism Research, $\mathrm{n}^{\circ} 13$ (4): 379-398.

\section{CST}

2003 "Certification for Sustainable Tourism (CST)". Retrieved 2 October 2015 from https://sustainabledevelopment.un.org

Dolezal, Claudia

2011 "Community-Based Tourism in Thailand: (Dis-) Illusions of Authenticity and the Necessity for Dynamic Concepts of Culture and Power", ASEAS - Austrian Journal of South-East Asian Studies, $\mathrm{n}^{\circ} 4$ (1): 129-138.

EAC

2010 "Criteria For Standardization of Hotels, Restaurants \& Other Tourist Accommodation Facilities of East Africa". Retrieved 1 October 2015 from http://www.eac.int/travel/index.php

Fennell, David

2006 Tourism ethics. Clevedon, Channel View Publications.

Fiorello, Amelie (and Damien Bo)

2012 "Community-Based Ecotourism to Meet the New Tourist's Expectations: An Exploratory Study", Journal of Hospitality Marketing \& Management, $n^{\circ} 21$ (7): 758-778.

FTT

No date "Certification standards". Retrieved 2 October 2015 from http://www.fairtrade.travel

Gartner, Candice (and Jhon Cukier)

2012 "Is tourism employment a sufficient mechanism for poverty reduction? A case study from Nkhata Bay, Malawi", Current Issues in Tourism, $\mathrm{n}^{\circ} 15$ (6): 545-562.

George, Brian (and others)

2007 "The Business of Community Based Tourism: A Multi-Stakeholder Approach", Tourism Issues, $\mathrm{n}^{\circ} 3$ : $1-19$.

Giampiccoli, Andrea (and others)

2015 "Community-based tourism in rich and poor countries: Towards a framework for comparison", African Journal for Physical, Health Education, Recreation and Dance, $\mathrm{n}^{\circ} 21$ (4:1): 1200-1216.

Giampiccoli, Andrea (and others)

2014 "International Cooperation, Community-Based Tourism and Capacity Building: Results from a Mpondoland Village in South Africa", Mediterranean Journal of Social Sciences, $n^{\circ} 5$ (23): 657-667.

Green Globe

No date "Green Globe Certification". Retrieved 2 October 2015 from http://greenglobe.com

Honey, Martha (and Raymond Gilpin)

2009 "Tourism in the Developing World. Promoting Peace and Reducing Poverty". Special Report 233 October 2009. Washington: United States Institute of Peace.

Ivanovic, Milena

2008 Cultural tourism. Cape Town, Juta \& Company.

Jugmohan, Sam (and Judith Steyn)

2015 "A Pre-Condition Evaluation and Management Model for Community-Based Tourism", African Journal for Physical, Health Education, Recreation and Dance, nº 21 (3:2): 1068-1084.

Kayat, Kalsom 
2014 "Community-Based Rural Tourism: A Proposed Sustainability Framework". SHS Web of Conferences 12, 01010.

Lancee, Bram (and Herman van de Werfhorst)

2011 "Income Inequality and Participation A Comparison of 24 European Countries". GINI Discussion Paper 6. Amsterdam Institute for Advanced labour Studies.

Leksakundilok, Amy (and Philip Hirsch)

2008 "Community-based tourism in Thailand", in J. Connell \& B. Rugendyke (eds.), Tourism at the grassroot. Villagers and visitors in the Asia-Pacific, $\mathrm{n}^{\circ} 2: 214-235$.

Loizos, Christou

2012 "Is it possible to combine mass tourism with alternative forms of tourism: the case of Spain, Greece,

Slovenia and Croatia". Journal of Business Administration Online - Spring 2012, 1-8. Retrieved 25

September 2015 from http://www.atu.edu/jbao

López-Guzmán, Tomás (and others)

2011 "Community-based tourism in developing countries: a case study", Tourismos: An International Multidisciplinary Journal of Tourism, $\mathrm{n}^{\circ} 6$ (1): 69-84.

Luo, Xianrong (and others)

2015 "Host perceptions of backpackers: Examining the influence of intergroup contact", Tourism Management, $\mathrm{n}^{\circ}$ 50: 292-305.

Manu, lan, (and William Kuuder)

2012 "Community-Based Ecotourism and Livelihood Enhancement in Sirigu, Ghana", International Journal of Humanities and Social Science, $n^{\circ} 2$ (18): 97-108.

Mtapuri Oliver (and Andrea Giampiccoli)

2014 "Towards a comprehensive model of community-based tourism development", South African Geographical Journal. DOI: 10.1080/03736245.2014.977813

Mtapuri Oliver (and Andrea Giampiccoli)

2013 "Interrogating the role of the state and nonstate actors in community-based tourism ventures: Toward a model for spreading the benefits to the wider community", South African Geographical Journal, $n^{\circ} 95(1): 1-15$.

Mtapuri, Oliver (and others)

2015 "Community-based tourism affinity index: a visitor"s approach", African Journal of Hospitality, Tourism and Leisure, $\mathrm{n}^{\circ} 4$ (2): 1-13.

Novelli, Marina

2016 Tourism and Development in Sub-Saharan Africa: Current issues and local realities. Abingdon, Routledge.

Núñez-Serrano, José Antonio (and others)

2014 "Are stars a good indicator of hotel quality? Assymetric information and regulatory heterogeneity in Spain", Tourism management, $\mathrm{n}^{\circ}$ 52: 77-87.

OECD

No date "Keeping the multiple dimensions of poverty at the heart of development. OECD and Post-2015". Element 1, paper 1. Retrieved 12 August 2015 from http://www.oecd.org/dac/POST

Oriade, Ade (and Mike Evans)

2011 "Sustainable and alternative tourism", in P. Robinson, S. Heitmann \& P. U. C. Dieke (eds.), Research Themes in Tourism. Wallingford, CABI: 69-86.

Pickett, Kate

2014 "Reducing Inequality: An Essential Step For Development And Well-Being". BREF Commentary.

Retrieved 12 August 2015 from http://www.bridgingeurope.net/uploads 
2013 "About Hotel Classification Systems". Retrieved 3 October 2015 from http://www2.unwto.org/agora

Radojevic, Tijana (and others)

2015 "Ensuring positive feedback: Factors that influence customer satisfaction in the contemporary hospitality industry", Tourism Management, $\mathrm{n}^{\circ}$ 51: 13-21.

Ramsa Yaman, Amat (and Abdullah Mohd)

2004 "Community-based Ecotourism: A New proposition for Sustainable Development and Environmental Conservation in Malaysia", Journal of Applied Science, $n^{\circ} 4$ (4): 583-589.

Rhee, Hosum Timothy (and Sung-Byung Yang)

2015 "Does hotel attribute importance differ by hotel? Focusing on hotel star-classifications and customers' overall ratings", Computers in Human Behavior, $n^{\circ}$ 50: 576-587.

Rifai, Taleb

2015a "Foreword", in UNWTO (ed.), Tourism in Africa: A Tool for Development. Madrid, Affiliate Members Regional Report, UNWTO, $\mathrm{n}^{\circ} 4$ (2).

2015b "Foreword", in World Tourism Organization (ed.), Hotel Classification Systems: Recurrence of criteria in 4 and 5 stars hotels. Madrid, UNWTO, $\mathrm{n}^{\circ} 5$.

Saarinen, Jarkko (and Christian Rogerson)

2014 "Tourism and the Millennium Development Goals: perspectives beyond 2015", Tourism Geographies, $n^{0} 16$ (1): 23-30.

Saayman, Melville (and Andrea Giampiccoli)

2016 "Community-based and pro-poor tourism: initial assessment of their relation to community development", European Journal of Tourism Research, $n^{\circ} 12: 145-190$.

Saayman, Melville (and others)

2012 "The impact of tourism on poverty in South Africa", Development Southern Africa, $\mathrm{n}^{\circ} 29$ (3): 462-487.

Scott, Nigel

2015 Distinguishing between community - based tourism and community benefit tourism: an example from China. Paper presentation at The International Conference on the 50th Anniversary of National Institute of Development Administration (NIDA), Tourism \& Hospitality Industry Studies (ICA-NIDA2015THIS), Theme "Integrated Tourism Management: A Way Forward to Sustainability", Bangkok 28th, 2015. Retrieved 26 September 2015 from http://tour.nida.ac.th/wp-content

Sharpley, Richard 2009 Tourism Development and the Environment: Beyond Sustainability? London, Earthscan.

Singh, Shalini (and others)

2003 "Tourism and destination communities", in S. Singh, D. J. Timothy \& R. K. Dowling (eds.), Tourism in destination communities. Wallingford, Cabi: 3-18.

Spilanis, loannis (and Helen Vayanni)

2004 Sustainable tourism: Utopia or necessity? Therole of new forms of tourism in the Aegean Islands, en B. Bramwell (ed), Costal mass tourism. Clevedon, Channel View Publications: 269-291.

Su, Ching-Shu (and Lou-Hon Sun)

2007 "Taiwan's Hotel Rating System: A Service Quality Perspective", Cornell Hotel and Restaurant Administration Quarterly, $n^{\circ} 48$ (4): 392-401.

Suansri, Potjana

2003 Community Based Tourism Handbook. Bangkok, Responsible Ecological Social Tour (REST).

Tamir, Meseret

2015 "Challenges and Opportunities of Community based Tourism Development in Awi Zone: A Case 
Study in Guagusa and Banja Woredas, Ethiopia”, Journal of Tourism, Hospitality and Sports, n 11: 50-78.

\section{TGCSA}

2013 "Minimum requirements: formal accommodation. Hotels and Lodges. Tourism Grading Council of South Africa". Retrieved 1 October 2015 from http://www.tourismgrading.co.za/assets

The European Consumer Centres' Network

No date Classification of hotel Establishments within the EU. Retrieved 1 October 205 from http://ec.europa.eu/consumers/ecc/docs

Tresilian, David

2006 Poverty Alleviation and Community Based Tourism: Experiences from Central and South Asia. Paris, UNESCO.

UNDP (United Nations Development Programme)

2013 Humanity Divided: Confronting Inequality in Developing Countries. New York, United Nations Development Programme.

UNEP

No date Negative Economic Impacts of Tourism. UNEP, Retrieved 25 September 2015 from http://www.unep.org/resourceefficiency/Business/SectoralActivities/Tourism

\section{UNWTO}

2015 Hotel Classification Systems: Recurrence of criteria in 4 and 5 stars hotels. UNWTO, Madrid.

Yoopetch, Carol

2015 Sustaining Community-Based Cultural Tourism in Thailand. Proceedings of the Third International Conference on Hospitality, Leisure, Sport, and Tourism, pp. 572-582. July 22-24, Waseda University, Tokyo, Japan. 